Check for updates

The BMJ

fgodlee@bmj.com Follow Fiona on Twitter @fgodlee

Cite this as: BMJ2021:375:n2963 http://dx.doi.org/10.1136/bmj.n2963 Published: 02 December 2021

\title{
Covid 19: Why we need a global pandemic treaty
}

\section{Fiona Godlee editor in chief}

The world was not prepared for this pandemic. While countries affected by severe acute respiratory syndrome (SARS) in 2003 responded quickly and efficiently to the early warnings of covid-19, most stumbled at the first hurdle and are still not catching up.

For a rich nation, the UK has performed particularly poorly. A damning report from a people's inquiry concludes that the government has been grossly negligent, amounting to misconduct in public office (doi:10.1136/bmj.n2955). ${ }^{1}$ And although lessons may have been learnt about procurement and stockpiling of personal protective equipment

(doi:10.1136/bmj.n2849), ${ }^{2}$ there is now a worrying and costly fixation on unproved antiviral drugs, with echoes of the Tamiflu saga (bmj.com/tamiflu). The UK was the first country, now followed by the US (doi:10.1136/bmj.n2984), ${ }^{3}$ to approve an antiviral for covid-19, on the evidence of a single clinical trial, apparently to fulfil an "impossible promise" by politicians to have two antivirals ready for use by the autumn (doi:10.1136/bmj.n2611). ${ }^{4}$ This despite incontrovertible evidence that the virus is airborne, that a combination of masks, screens, social distancing, and ventilation can stop transmission (see our interactive graphic bmj.com/content/375/bmj-2021-065312/infographic), and that the real money must urgently go on improving indoor air quality (doi:10.1136/bmj.n2895). ${ }^{5}$

Each country has had its own reasons for failures in preparing for emergencies, including wrong assumptions about potential threats. For the UK it was flu, for the US bioterrorism, prompting stockpiles of smallpox vaccine and nerve gas antidote (doi:10.1136/bmj.n2849). ${ }^{2}$ Paradoxically perhaps, some countries in Africa have shown what can be done, using their hard won understanding of health emergencies (doi:10.1136/bmj.n2512). ${ }^{6}$ Their response included the genome sequencing that alerted the world to the new variant, omicron.

How should countries respond to omicron? Some have closed their borders (doi:10.1136/bmj.n2943), ${ }^{7}$ but stopping incoming flights from southern Africa is surely political and pointless and will damage international collaboration. Instead we need effective quarantine, contact tracing, and testing of travellers. And we should tighten preventive precautions until we know more (doi:10.1136/bmj.n2941). ${ }^{8}$

Covid-19 has laid bare national but also global shortcomings, writes WHO's director general, Tedros Adhanom Ghebreyesus

(https://blogs.bmj.com/bmj/2021/09/16/what-is-themissing-ingredient-in-global-pandemic-preparedness-and-response), ${ }^{9}$ as part of two major $B M J$ collections of articles on pandemic preparedness published this week (bmj.com/global-pandemictreaty; bmj.com/covid-19-preparedness-and-re- sponse). We need to revamp the world's collective response, Tedros says. Key to that revamping will be a legally binding international treaty on pandemic preparedness and response, with a commitment to sharing data, information, resources, knowledge, and tools.

The world was not prepared for this pandemic (doi:10.1136/bmj-2021-067518). ${ }^{10}$ We need a global treaty if we are to prepare for the next one.

Dyer C. Covid-19: Government was "grossly negligent" in its handling of pandemic, says people's inquiry. BM/2021;375:n295.

2 Feinmann J. What happened to our national emergency stockpiles?BMJ 2021;375:n2849. doi: 10.1136/bmi.n2849 pmid: 34848399

3 Dyer O. Covid-19: FDA expert panel recommends authorising molnupiravir but also voices concerns. BM/2021;375:n2984

4 Sidebottom DB, Smith DD, Gill D. Safety and efficacy of antivirals against SARS-CoV-2. BM/2021;375:n2611.pmid: 34711614

5 Dancer SJ, Bluyssen PM, Li Y, Tang JW. Why don't we just open the windows?BM/2021;375:n2895. doi: 10.1136/bmi.n2895 pmid: 34836876

6 Senthilingam M. Covid-19: Why Africa's pandemic is different. BMJ 2021;375:n2512. doi: 10.1136/bmj.n2512 pmid: 34667031

7 Torjesen I. Covid-19: Omicron may be more transmissible than other variants and partly resistant to existing vaccines, scientists fear. BMJ 2021;375:n2943. doi: 10.1136/bmj.n2943 pmid: 34845008

8 Salisbury H. Helen Salisbury: Omicron-panic mongering or appropriate caution?BMJ 2021;375:n2941. doi: 10.1136/bmj.n2941 pmid: 34845004

9 Ghebreyesus TA. What is the missing ingredient in global pandemic preparedness and response? BMJ Opinion. Sep 2021 https://blogs.bmi.com/bmi/2021/09/16/what-is-the-missing-ingredient-inglobal-pandemic-preparedness-and-response.

10 Singh S, Bartos M, Abdalla S, etal. Resetting international systems for pandemic preparedness and response. BMJ 2021;375:e067518 doi: 10.1136/bmj-2021-067518 pmid: 34840131

This article is made freely available for use in accordance with BMJ's website terms and conditions for the duration of the covid-19 pandemic or until otherwise determined by BMJ. You may use, download and print the article for any lawful, non-commercial purpose (including text and data mining) provided that all copyright notices and trade marks are retained. 